\title{
The Competitive Advantage of Batik SMEs Based on a Learning Organization
}

\author{
Reni Shinta Dewi ${ }^{1}$, Ari Pradhanawati ${ }^{2}$ \\ \{renishinta@yahoo.co.id ${ }^{1}$ \} \\ Universitas Diponegoro, Indonesia ${ }^{1,2}$
}

\begin{abstract}
Globalization has come to a new era of revolution of industry 4.0. The presence of this era is inevitable, for it has not only an extraordinary potential in remodeling the industry but also changing many aspects of human lives. To deal with these changes, SMEs must learn to gain new knowledge and spread it to all members of the organization. The purpose of this research is to develop a competitive advantage model based on organizational learning. This study was conducted on the largest of batik SMEs industry cluster in Central Java, namely Kampoeng Laweyan, Solo. The quantitative approach is used with the survey method. The number of samples is 100 UKM. Analyzes were performed using the Statistical Package for Social Sciences (SPSS). Factor analysis shows that organizational learning is formed from acquisition, dissemination, and shared interpretation. The results show that shared interpretation has a significant effect on competitive advantage, while acquisition and dissemination have no significant effect on competitive advantage. Even so, organizational learning has a significant effect on competitive advantage. This finding is in line with Learning Theory, where organizational learning is a way to open up competitive advantages.
\end{abstract}

Keywords: Competitive Advantage, Organizational Learning, SMEs

\section{Introduction}

The emergence of the Industrial Revolution 4.0, forced organizations to change and adapt. Organizations seek to remain competitive by using various strategies and theories as tools to solve problems, as well as to increase the company's long-term profitability and sustainable competitiveness. A knowledge-based view provides a firm view of the relevance of knowledge as a key organizational factor [1][2] and is one of the main determinants of a company's existence. The ability to learn and Organizational learning is an ongoing advantage of organizations. To maintain knowledge, organizational learning is an important key to longterm organizational survival, performance, and continuous improvement [3]. It can be identified as a knowledge process, in which knowledge is acquired, shared, understood, and stored [4]. Moreover, one main objective of organizational learning is to share knowledge within the organization and with different partners to retain this knowledge.

Organizational learning is a source of competitive advantage. It helps organizations respond to environmental changes and adopt innovations that will improve their performance. Organizational learning has been viewed as new insights and modified behaviors. Previous researchers have argued that the use of innovation is made possible primarily by appropriate learning strategies [5][6][7][8][9]. Learning increases an organization's ability to adapt to changes in a competitive environment and successfully implement strategic changes that are 
appropriate for performance improvement [10][11]. Various studies have been carried out by researchers in revealing the existence of Organizational learning, especially for SMEs.

Research conducted by Santos-Vijande and Álvarez-González [12], explains that the findings confirm the expected relationship and reveal that Organizational learning is an important instrument in the modern market to provide customer value and increase organizational performance through efficient competitive, strategy design, and flexible adaptations for rapid market evolution. Organizational learning is the key to organizational capabilities in dealing with rapidly changing market changes. These findings are in line with Pastuszak et al. [13], where knowledge and learning abilities are very important factors in the competitive advantage of an organization. Knowledge from internal and external sources must be transferred to all levels of the organization. The main contribution of this research is to explore organizational learning in SMEs to achieve a competitive advantage.

\section{Material and Method}

\subsection{Measures}

Organizational learning (OL) is measured using 3 dimensions that adopt research from Santos-Vijande and Álvarez-González [12], namely information acquisition, information dissemination, and shared interpretation with a 5-point Likert scale. The results of validity and reliability tests show all dimensions are valid $(>.60)$ and reliable $(>.70)$.

Competitive advantage. The measurement uses a 5-point Likert scale by adopting the 3 dimensions of Porter and Advantage [14], namely cost leadership, differentiation, and focus. The results of the validity and reliability test show all dimensions are valid $(>.59)$ and reliable $(>.80)$.

\subsection{Data Analysis}

The research was conducted at the largest batik industrial center in Laweyan-Solo, Central Java, Indonesia. Data were collected for 6 (two) weeks by visiting respondents after getting time to meet. Besides, the use of the batik community (social capital) was carried out to obtain a high response rate [15]. We received a total of 100 complete questionnaires. We found that the sample structure matched the population with the goodness of fit test [16]. The data collected from the questionnaire were analyzed using the Statistical Package for Social Sciences (SPSS). Factor analysis was carried out to determine organizational learning factors. Regression analysis is used to examine the effect of the independent variable on the dependent variable.

\section{Result and Discussion}

In table 1, gender had a balanced proportional between Male (55\%) and Female (45\%). In terms of education, most of the respondents have high school education (71\%), while $10 \%$ have a diploma degree and $12 \%$ have graduated from S1. Most of the respondents stated that the businesses that were run have legal entities including UD, CV and had SIUP. Most of the SMEs were established in the $2000-2010$ period. 
Table 1. Demographics Information

\begin{tabular}{|c|c|c|}
\hline Characteristics & Freq $(N=191)$ & Percentage (\%) \\
\hline \multicolumn{3}{|l|}{ Gender } \\
\hline Male & 55 & 55 \\
\hline Female & 45 & 45 \\
\hline \multicolumn{3}{|l|}{ Education } \\
\hline Elementary School & - & - \\
\hline Secondary School & 5 & 5 \\
\hline High School & 71 & 71 \\
\hline Diploma & 10 & 10 \\
\hline B.Sc & 12 & 12 \\
\hline M.Sc & 2 & 2 \\
\hline \multicolumn{3}{|l|}{ Legal Entity } \\
\hline Yes & 65 & 65 \\
\hline Not & 35 & 35 \\
\hline \multicolumn{3}{|l|}{ Established since } \\
\hline$<2000$ & 35 & 35 \\
\hline $2000-2010$ & 43 & 43 \\
\hline$>2010-2020$ & 22 & 22 \\
\hline
\end{tabular}

Factor analysis was used to test 16 factors constituting organizational learning. The solution of the three factors was obtained by extracting factors with the eigenvalue more than 1, which explained 50.639 percent variants (statistic Kaiser-Meyer-Olkin 0.852; Bartlett test of specificity 299.391; significance of 0.000). Loading factor was shown in Table I. Loading factor in each factor exceeded 0.50.

Table 2. Analysis Factor of Organizational Learning

\begin{tabular}{|c|c|c|c|}
\hline & Factor 1 & Factor 2 & Factor 3 \\
\hline Cooperation with other companies & & & .713 \\
\hline Cooperation with professional expert technicians & & & .854 \\
\hline $\begin{array}{l}\text { Product change policy through discussions with } \\
\text { employees }\end{array}$ & .681 & & \\
\hline $\begin{array}{l}\text { New ideas and approaches in making batik are } \\
\text { continuously tried }\end{array}$ & .614 & & \\
\hline $\begin{array}{l}\text { Organizational systems and procedures support } \\
\text { Innovation }\end{array}$ & .680 & & \\
\hline Encourage its employees to join the network & .686 & & \\
\hline Understand the Company's goals & & .641 & \\
\hline $\begin{array}{l}\text { Meetings are held regularly to explain about the } \\
\text { latest innovations }\end{array}$ & & .644 & \\
\hline The company has a clear division of labor & .617 & & \\
\hline $\begin{array}{l}\text { The company accommodates suggestions from } \\
\text { employees }\end{array}$ & .833 & & \\
\hline $\begin{array}{l}\text { Organization members have the same goals as the } \\
\text { Organization }\end{array}$ & & .568 & \\
\hline Employees share knowledge and experience & .846 & & \\
\hline
\end{tabular}




\begin{tabular}{|l|c|c|c|}
\hline $\begin{array}{l}\text { Collaboration is a very common practice in } \\
\text { companies }\end{array}$ & .754 & & \\
\hline $\begin{array}{l}\text { The company has a directory (web) or email and } \\
\text { is always updated }\end{array}$ & & .848 & \\
\hline $\begin{array}{l}\text { The company maintains an up-to-date database of } \\
\text { its clients }\end{array}$ & & .913 & \\
\hline The client/consumer database is always up to date & & .913 & \\
\hline Eigenvalue & 8.102 & 1.978 & 1.127 \\
\hline Per cent of variance & 50.639 & 12.361 & 7.046 \\
\hline
\end{tabular}

The analysis result of factors towards organizational learning was in line with the research conducted by Santos-Vijande and Álvarez-González [12] consisting of three factors:

a) Factor 1 represented the sharing of interpretation, the process of finding the meaning of the information received.

b) Factor 2 was information dissemination, the process for explaining the information received and the exchange of information that can provide benefits to the organization.

c) Factor 3 was information acquisition, shows a collection and determination of customer needs or preferences (such as internal purchases) and challenges from the organization, (such as steps to be taken, and the macro environment) that can influence the development of the organization and clarify those needs.

Table 3. Regression Analysis

\begin{tabular}{|l|c|c|c|c|}
\hline \multicolumn{1}{|c|}{ Model Hypotheses testing } & $\boldsymbol{\beta}$ & $\mathbf{t}$ & Sig. & Supported/Not Supported \\
\hline Sharing of Interpretation & 0.222 & 1.345 & 0.182 & Not Supported \\
\hline Information Dissemination & 0.393 & 2.382 & 0.019 & Supported \\
\hline Information Acquisition & 0.128 & 0.774 & 0.441 & Not Supported \\
\hline
\end{tabular}

a. Dependent Variable: Competitive Advantage

Table 4. Multiple Regression Analysis

\begin{tabular}{|l|c|c|c|c|c|c|}
\hline \multirow{2}{*}{ Model } & \multicolumn{6}{|c|}{ Change Statistics } \\
\cline { 3 - 7 } & $\begin{array}{c}\text { R. Square } \\
\text { Change }\end{array}$ & F Change & df1 & df2 & $\begin{array}{c}\text { Sig. F } \\
\text { Change }\end{array}$ \\
\hline Dimension & 1 & $.078^{\mathrm{a}}$ & 2.694 & 3 & 96 & 0.04 \\
\hline
\end{tabular}

a. Predictors: (Constant), REGR factor score 3 for analysis 3, REGR factor score 2 for analysis 3 , REGR factor score 1 for analysis 3 .

The results show that Information Dissemination has a significant effect on competitive advantage (Sig. 0.019), while Information Acquisition and Sharing Interpretation have no significant effect on competitive advantage (Sig. 0.182; 0.441). The results of multiple regression indicate that organizational learning has a significant positive effect on competitive advantage.

Organizational learning occurs when a firm develops new knowledge and insights from the common experiences of people in the organization, and it has the potential to influence the range of organizational behaviors and improve the firm's capabilities [4][17]. Knowledge shows individual behavior and becomes a source of competitive advantage must be transformed into organizational knowledge [18][19][20].

In the Batik industry, information dissemination is the biggest factor in creating a competitive advantage. The Covid-19 pandemic has stopped all businesses and entrepreneurs 
can only wait for what information that they can use to deal with the outbreak. Paguyuban becomes an information center to share information related to strategies that must be carried out by SMEs.

\section{Conclusion}

The result in line with Huber [4] and DiBella et al. [21], that organizational learning consists of knowledge exploitation (integration of learning so that it is assimilated, broadly available and can be generalized to new situations), knowledge sharing (dissemination to others of what has been acquired by some) and knowledge acquisition (development or creation of skills, insights and relationships).

This finding is in line with Learning Theory, where organizational learning is a way to open up competitive advantages. Knowledge shows individual behavior and becomes a source of competitive advantage must be transformed into organizational knowledge [18][19][20].

\section{References}

[1] M. Zack, "Developing a knowledge strategy', California Management Review," vol, vol. 41, pp. I25-145, 1999.

[2] J. Darroch, "Knowledge management, innovation and firm performance," J. Knowl. Manag., 2005.

[3] G. Yukl, "Leading organizational learning: Reflections on theory and research," Leadersh. Q., vol. 20 , no. 1 , pp. 49-53, 2009.

[4] G. P. Huber, "Organizational learning: The contributing processes and the literatures," Organ. Sci., vol. 2, no. 1, pp. 88-115, 1991.

[5] T. K. Lant and S. J. Mezias, "An organizational learning model of convergence and reorientation," Organ. Sci., vol. 3, no. 1, pp. 47-71, 1992.

[6] P. Attewell, "Technology diffusion and organizational learning: The case of business computing," Organ. Sci., vol. 3, no. 1, pp. 1-19, 1992.

[7] S. J. Mezias and M. A. Glynn, "The three faces of corporate renewal: Institution, revolution, and evolution," Strateg. Manag. J., vol. 14, no. 2, pp. 77-101, 1993.

[8] R. G. Fichman and C. F. Kemerer, "The assimilation of software process innovations: An organizational learning perspective," Manage. Sci., vol. 43, no. 10, pp. 1345-1363, 1997.

[9] M. Schulz, "Limits to bureaucratic growth: The density dependence of organizational rule births," Adm. Sci. Q., pp. 845-876, 1998.

[10] P. Windrum, "Late entrant strategies in technological ecologies: Microsoft's use of standards in the browser wars," Int. Stud. Manag. Organ., vol. 31, no. 1, pp. 87-105, 2001.

[11] S. P. Lopez, J. M. M. Peón, and C. J. V. Ordás, "Organizational learning as a determining factor in business performance," Learn. Organ., 2005.

[12] M. L. Santos-Vijande and L. I. Álvarez-González, "Innovativeness and organizational innovation in total quality oriented firms: The moderating role of market turbulence," Technovation, vol. 27, no. 9, pp. 514-532, 2007.

[13] Z. Pastuszak, S. H.-P. Shyu, T.-R. Lee, P. Anussornnitisarn, and O. Kaewchur, "Establishing interrelationships among organisational learning, innovation and performance," Int. J. Innov. Learn., vol. 11, no. 2, pp. 200-215, 2012.

[14] M. E. Porter and C. Advantage, "Creating and sustaining superior performance," Compet. Advant., vol. 167, pp. 167-206, 1985.

[15] P. Newbold, W. L. Carlson, and B. Thorne, Statistics for business and economics. Pearson Boston, MA, 2013.

[16] L. Yuan, L. Zhou, G. Bruton, and W. Li, "Capabilities as a mediator linking international 
diversification and innovation performance of firms in an emerging economy," J. Bus. Res., vol. 69, no. 8, pp. 2678-2686, 2010.

[17] S. F. Slater and J. C. Narver, "Market orientation and the learning organization," J. Mark., vol. 59, no. 3, pp. 63-74, 1995.

[18] R. M. Grant, "Toward A Knowledge- Based Theory of the Firm," Strateg. Manag. J. ', vol. 17, no. Winter Special, 1996.

[19] I. Nonaka and N. Konno, "The concept of 'Ba': Building a foundation for knowledge creation," Calif. Manage. Rev., vol. 40, no. 3, pp. 40-54, 1998.

[20] W. W. Powell, "Learning from collaboration: Knowledge and networks in the biotechnology and pharmaceutical industries," Calif. Manage. Rev., vol. 40, no. 3, pp. 228-240, 1998.

[21] A. J. DiBella, E. C. Nevis, and J. M. Gould, "Understanding organizational learning capability," J. Manag. Stud., vol. 33, no. 3, pp. 361-379, 1996. 